\title{
Mycket, men på låtsas
}

\author{
Vad studenter egentligen lär sig av "miniprojekt" inom ramen för högskolekurser i \\ vetenskaplig teori och metod.
}

\author{
Sverker Lundin \\ Institutionen för pedagogik och specialpedagogik, Göteborgs universitet
}

I artikelns fokus står ett upplägg för kurser i vetenskaplig teori och metod, där studenter under strikt reglerade former får genomföra "miniprojekt" för att lära sig arbeta med sådant som intervju, observation, enkät och dokumentanalys. Kursupplägget ger sken av att ett stort antal studenter, med skiftande bakgrundskunskaper, på kort tid och med stor förutsägbarhet, når ofta ganska storslagna lärandemål. Artikelns huvudpoäng är att det emellertid rör sig just om sken, och inte om en verklig erfarenhet av det vetenskapliga hantverket. En stor del av artikeln ägnas åt att med hänvisning till ritualteori och psykoanalytiskt inspirerad kulturteori förklara varför denna typ av kursupplägg accepteras, trots att såväl lärare som studenter ofta är medvetna om det glapp mellan sken och verklighet som kursupplägget ger upphov till.

Nyckelord: Högskolepedagogik, ideologikritik, vetenskaplig metod

\section{INLEDNING ${ }^{\mathrm{I}}$}

Under de senaste 150 åren har allt fler människor kommit att spendera allt längre tid i olika former av utbildning. Vad gäller svenska förhållanden kan man spåra denna utveckling genom skolplikten, vilken infördes som sexårig 1882 och sedan dess utsträckts till att idag vara tioårig. I praktiken har utbildningssystemets expansion varit ännu mer omfattande i och med att först gymnasieutbildning och sedan högskoleutbildning allt mer kommit att utgöra ett obligatorium för normalt deltagande i samhälls- och arbetsliv. Sedan högskolereformen 1977 har en mängd yrkesutbildningar flyttat in i högskolan och även traditionella universitetsdiscipliner förväntas idag i stor utsträckning fungera yrkesförberedande genom att efter bästa förmåga bidra till att göra studenterna anställningsbara. Tendensen kan illustreras av den så kallade "bolognaprocessen" som sedan slutet av I990-talet verkat för att standardisera och effektivisera den högre utbildningen i Europa (information om denna process kan man hitta på ehea.info; för en kritik se Pongratz, 2009). Bolognaprocessen har bland annat satt avtryck i Sverige genom den så kallade "bolognareformen" 2007, genom vilken högskoleförordningen berikades med explicit formulerade "lärandemål" för alla svenska högskoleexamina (se t.ex. Utredningen om högskolans utbildningsutbud, 20I5).

Några av de termer som inom forskningen används för att beskriva och förklara utbildningssystemets expansion är pedagogisering (Depaepe \& Smeyers, 2008; Ribolits \& Zuber, 2004; Höhne, 2003), förskolning (Lundin, Dodillet \& Storck Christensen, 20I8), akademisering (för läraryrket se Broady, Börjesson \& Bertilsson, 2009 samt Dodillet, Lundin \& Krüger 20I8; för
1 Jag vill tacka Susanne Dodillet, Leo Berglund och Ditte Storck-Christensen, två anonyma reviewers samt Anders Sonesson i redaktionen för Högre utbildning för värdefulla synpunkter under arbetet med denna artikel.

*Författarkontakt: sverker.lundin@gu.se

Artiklar och reflektioner är kollegialt granskade. Övriga bidragstyper granskas av redaktionen. Se www.hogreutbildning.se ISSN 2000-7558

(C) 2019 Sverker Lundin. This is an Open Access article distributed under the terms of the Creative Commons Attribution-NonCommercial 4.0 International License (https://creativecommons.org/licenses/by-nc/4.0/), allowing third parties to share their work (copy, distribute, transmit) and to adapt it, under the condition that the authors are given credit, that the work is not used for commercial purposes, and that in the event of reuse or distribution, the terms of this license are made clear.

Citation: Sverker Lundin (2019) «Mycket, men på låtsas», Högre utbildning, 9(2), 1-14. http://dx.doi.org/10.23865/hu.v9.1497 


\section{Sverker Lundin}

sjuksköterskeyrket se Lundin \& Petersen, 2005) och professionalisering (Brante, 2009; Brante, 20II; Krejsler, 2005). Forskningen visar att utbildning kommit att behandlas som ett universellt framgångsrecept i det moderna samhället: den ska göra individer anställningsbara och ge dem rätt värderingar; den ska höja enskilda yrkesgruppers status genom att omvandla dem till professioner; den ska förbättra demokratin och den ska stärka samhällets ekonomiska tillväxt.

Det övergripande syftet med den här artikeln är att argumentera för att högskolan möter denna storslagna förväntan genom att i och för sig leverera allt mer kunskaper, på ett allt mer effektivt sätt, med högre precision (definierade av "lärandemål"), till en allt bredare grupp studenter - men med den betydande nackdelen att detta åtminstone i vissa fall sker på låtsas snarare än på riktigt. Vad detta innebär kommer i det följande att förklaras i anslutning till ett specifikt upplägg för kurser i vetenskaplig teori och metod som jag själv arbetat med under många år, bland annat inom ramen för utbildning av lärare, förskolelärare, folkhälsovetare, personalvetare, specialpedagoger och speciallärare. De kursplaner och kursguider som jag hänvisar till har hämtats från denna yrkesverksamhet.

\section{UNDERVISNING SOM SKAPAR ETT SKEN AV LÄRANDE}

Ett centralt moment i det kursupplägg som står i fokus för analysen i den här artikeln är "miniprojekt" i form av korta observationsstudier, intervjustudier, enkätstudier och/eller dokumentanalysstudier. Angående dessa miniprojekt kan man i en kursguide läsa:

Syftet med denna uppgift [intervjustudien] är att ge inblick i fyra aspekter av det vetenskapliga hantverket. Ni ska i grupp, för det första, formulera en fråga så att den kan undersökas empiriskt. För det andra ska gruppen generera empiriska data. För det tredje ska ni analysera data, så att frågan kan besvaras. Slutligen ska ni kommunicera studien och dess resultat på ett kort och begripligt sätt [...]

Varje studie ska genomföras inom loppet av lite drygt en vecka enligt ett givet schema: en eftermiddag ägnas åt "planering", sedan följer en och en halv dags "genomförande", följt av en eftermiddags "planering av presentation" och slutligen en avslutande redovisning.

Jag vill föreslå att studenternas och lärarnas handlande utifrån denna kursguide förstås som uppförandet av ett skådespel, med dem själva som i stort sett enda publik. Vad kursguiden säger är i princip att studenterna ska "härma" riktig forskning. Syftet med detta härmande är så klart att studenterna ska lära sig. Men till skillnad från tolkningen i termer av lärande sätter tolkningen i termer av uppförande - som jag kommer att kalla det - fokus på den stiliserade formen hos detta verklighetshärmande. Studenterna måste så att säga "uppföra sig", först och främst genom att vara på plats - närvaro är obligatorisk - men även genom att "spela med". Att "uppföra sig" innebär i denna typ av kurser att vara "aktiv". Tolkningen i termer av uppförande tar vidare fasta på att denna stiliserade form är resultatet av att såväl studenternas som lärarnas handlande i stor utsträckning är föreskrivet, som av ett manus: kursguiden. Att vara aktiv innebär att man ska delta i föreskrivna "aktiviteter". Slutligen passar tolkningen i termer av uppförande det faktum att ungefär samma förlopp utspelar sig varje gång samma kurs ges, i stor utsträckning oberoende av vilka personer som deltar. Både då det rör sig om en kurs och om en pjäs är denna konstans och geografiska invarians en följd inte bara av det gemensamma manuskriptet, utan även av att samma praktiska omständigheter är så att säga uppställda överallt där kursen eller pjäsen ges, samt att praktiken är föremål för värderande granskning: likt en teaterrecensent bedömer läraren 
studenternas prestationer utifrån kriterier som är lika konstanta och geografiskt invarianta som kursguidens formuleringar och klassrummens möblering. ${ }^{2}$

Med denna tolkningen av miniprojekten som uppförandet av en sorts "forskningspjäs" vill jag sätta frågetecken bakom föreställningen att denna aktivitet skulle göra studenterna till bättre forskare. För det är ju knappast någon som tror att en roll som statsminister i en pjäs skulle utgöra en ändamålsenlig förberedelse för att vara statsminister på riktigt. Varför skulle man då tro att en student som är skicklig på att gestalta en duktig forskare därför också skulle vara förmögen att forska på riktigt?

Tolkningen av miniprojekten som uppförande öppnar för en analys av detta kursupplägg som en ritual. Enligt den amerikanske antropologen Roy Rappaport (1999) kan ritualiserat handlande nämligen förstås som ett noga reglerat gestaltande av ett visst meningsinnehåll, vilket genom ritualens utförande blir verkligt - enligt den myt som ritualen hänger samman med. Det teoretiska budskapet hos den högskolepedagogik som idag får allt större utrymme inom högskolan passar bra med denna tolkning. I en inflytelserik artikel förklarar Biggs (1996) att det bara är genom att vara "aktiva" som studenter kan "konstruera" nya kunskaper. Om det tidigare var upp till den enskilde studenten att hitta vägar att tillgodogöra sig ett av läraren tillhandahållet stoff, är det numera högskolepedagogikens uppgift att ge alla studenters handlande en ändamålsenlig form som mer eller mindre ofelbart leder dem till på förhand definierade lärandemål (se även Biggs \& Tang, 20II). Högskolepedagogiken förklarar varför studenternas meningsfyllda uppförande inom kursens ramar leder till en konstruktion av de kunskaper som lärandemålen definierar.

Utifrån ett ritualteoretiskt perspektiv kan man säga att högskolepedagogiken därmed tillhandahåller den myt genom vilken noga reglerade läraktiviteter kan motiveras. Men på ett sätt som är typiskt för relationen mellan ritual och myt är det få studenter och lärare som har någon djupare kunskap om pedagogisk teori, och det är definitivt inte på grund av kunskap om sådan teori som de gör som de gör. Som man kan förvänta sig när det gäller en ritual, är det istället så att både formen (ritualen) och innebörden (myten) hos den typ av studentaktivt lärande som högskolepedagogiken förespråkar har djupa, mångförgrenade och för de allra flesta helt okända historiska rötter. ${ }^{3}$

Vad jag vill föreslå är alltså att studenternas arbete med miniprojekt ska förstås som ett deltagande i en ritual som gestaltar forskning. Denna tolkning sätter fokus på att studenterna (och i viss mån även lärarna), när de deltar i kursen, måste förhålla sig till två parallella händelseförlopp:

- $\AA ̊$ ena sidan befinner de sig i skädespeleriets händelseförlopp. Detta kan betraktas som ett arbete, ett studentarbete, som präglas av alldaglig rutin och som utspelar sig i

2 Jag följer här Rappaports definition av "ritualens form" (1999, s. 23ff). Rappaport säger att en ritual karaktäriseras av att de deltagandes handlande är "bestämt av andra än de själva"; att handlandet är formalistiskt och noga övervakat; att handlandet är mer eller mindre konstant och geografiskt invariant; att det äger rum på en för ändamålet särskilt ägnad plats och att det följer en egen rytm och en egen logik, separerad från det övriga samhällslivets. Liknelsen med skådespeleri är inspirerad av den österrikiske filosofen Robert Pfaller (2002).

3 Idéerna har sitt ursprung i det tidiga 1900-talets progressiva pedagogik, vilken i sin tur opererar med ett tankegods som ursprungligen utvecklades inom tyskspråkig filosofi och teologi under slutet av 1700-talet (Oelkers, Osterwalder \& Tenorth, 2003). Denna filosofi och teologi har i sin tur rötter som sträcker sig tillbaka till modernitetens ursprung (Gillespie, 2008; Harrison, 2008; Pfau, 2013). För en beskrivning av hur ett progressivistiskt pedagogiskt ideal introduceras i den svenska folkskolan se Lundin, 2012b. 


\section{Sverker Lundin}

högskolans lokaler under några veckor. Det är ett strikt övervakat och regelföljande arbete, där kriterierna för acceptabelt uppförande definieras av kursguiden och som betalar sig i form av ett betyg som kan ingå i en examen.

- $\AA$ andra sidan måste studenterna förhålla sig till det gestaltade händelseförloppet. Det som gestaltas är forskning. Det är oklart vilka dessa tänkta forskare är som genomför en intervjustudie eller dokumentanalys; det är oklart varifrån de fått sina forskningsmedel och under hur lång tid deras forskningsprojekt egentligen pågår. Men eftersom gestaltandet är fokuserat på forskningsprocessens nyckelmoment - formulerandet av forskningsfrågan, skapandet av en intervjuguide eller ett observationsschema och så vidare - så framgår det (som i en pjäs) att det är exemplarisk forskning det rör sig om.

En viktig poäng inom (den modernare) ritualteorin (Rappaport, 1999) är att deltagare i ritualer vanligtvis är fullt förmögna att skilja mellan dessa två aspekter av deras handlande. Att medverka till uppförandet av en ritual innebär, kan man säga, att handla som om man gjorde något som alla medverkande samtidigt är mer eller mindre medvetna om att man rent faktiskt inte gör. I vårt fall handlar studenterna som om de forskade, samtidigt som de är väl medvetna om att det inte är fråga om forskning på riktigt. Med en terminologi hämtad från psykoanalysen kan man säga att den mening som kursupplägget gestaltar är genomskådad (Pfaller, 2002). Deltagarna är med andra ord inte fångade i den fantasivärld som ritualen gestaltar, även om de mycket väl kan leva sig in i den känslomässigt. Alla vet att det inte är fråga om forskning på riktigt, men på ett sätt som liknar skådespel och lek är detta faktum förnekat. Praktiken får sin särart genom att de medverkande blundar för en aspekt av sitt eget vetande (jfr. Lundin \& Wessely, 20I9).

Att genomskådande är nödvändigt blir tydligt i de undantagsfall då studenter, eller för den delen lärare, missförstår sin roll och försöker forska på riktigt inom kursens ramar. Sådana studenter och lärare kan till exempel ta den låtsade ambitionen att ställa en forskningsfråga på allvar, och inte nöja sig med de attrapper till forskningsfrågor som tas fram under den enligt manus för ändamålet avsedda eftermiddagen. Sådana studenter och lärare kan bli mycket frustrerade över kursuppläggets begränsningar. För studenternas del kan det autentiska engagemanget leda till svårigheter att producera ett godkänt resultat. För lärares del - och här talar jag utifrån egen erfarenhet - kan det leda till svårigheter att producera en i institutionsledningens ögon "godkänd" kurs.

Vad undantagen illustrerar är att det som krävs av studenter och lärare i dessa kurser inte är så trivialt som det i förstone kan verka. De måste ta kursen på allvar såtillvida att de är närvarande med åtminstone en minimal inlevelse. Men de ska inte ta kursen på så stort allvar att de försöker göra det som kursguiden säger att de ska göra, på riktigt. Med den freudianska term som introducerades ovan kan man säga att kursupplägget kräver att studenter och lärare i tysthet förnekar glappet mellan det som de egentligen gör (följer regler), och det som deras handlande utger sig för att vara (forskning).

\section{HUR SKENBARA KUNSKAPER INTEGRERAS I VERKLIGHETEN}

En av kurserna jag arbetat med har följande lärandemål:

Kunskap och förståelse

- redogöra för centrala vetenskapsteoretiska och metodologiska begrepp inom det pedagogiska området

- visa förtrogenhet med den vetenskapliga rapportens uppbyggnad och form 
- redogöra för forskningsprocessens olika steg

- förklara relationen mellan teoretiska antaganden och val av metod för insamling och analys av empiriska material

- redogöra för hur trovärdighet kan bedömas i olika studier

\section{Färdighet och förmåga}

- kritiskt granska vetenskapliga studier inom det pedagogiska området

- ur ett metodperspektiv göra självständiga och kritiska bedömningar av vetenskapliga studiers genomförande och resultat

- formulera en forskningsfråga som tar sin utgångspunkt i något vetenskapsteoretiskt perspektiv

- tillämpa olika metoder för insamling och analys av olika typer av empiriskt material

- tillämpa akademiskt skrivande inklusive ett system för referenshantering

\section{Värderingsförmåga och förhållningssätt}

- identifiera grundläggande etiska problem i forskningsprocessen och relatera dem till forskningsetiska principer

Frågan jag vill ställa i relation till dessa formuleringar är om de bäst passar ihop med skådespeleriets händelseförlopp av regelstyrd verksamhet under kort tid, eller den gestaltade meningens händelseförlopp av exemplarisk forskning. Syftet med denna fråga är att sätta fokus på att det som studenterna enligt lärandemålen förväntas ha lärt sig genom kursen är förmågor som man egentligen bara kan tillägna sig genom mycket längre erfarenhet, och erfarenhet dessutom av ett slag som är väsensskild från den som kursen erbjuder. Det är med andra ord, menar jag, bara utifrån det gestaltade meningsinnehållets perspektiv som målen framstår som rimliga. Bara utifrån tanken att studenterna i kursen får erfarenhet av exemplarisk forskning framstår det som rimligt att studenterna genom kursdeltagandet kan nå lärandemål som "förtrogenhet med den vetenskapliga rapportens uppbyggnad och form", "förmågan att formulera en forskningsfråga som tar sin utgångspunkt i något vetenskapsteoretiskt perspektiv" eller "förmågan att tillämpa olika metoder för insamling och analys av olika typer av empiriskt material". För förtrogen blir man ju i regel bara genom lång erfarenhet. Hur skulle man kunna bli förtrogen på några veckor? På samma sätt utgör förmågan att formulera en forskningsfråga något man möjligen kan utveckla under en forskarutbildning, och då i nära anslutning till ett visst forskningsfält, men säkert inte med utgångspunkt från ett "vetenskapsteoretiskt perspektiv", som man nyss blivit introducerad till, inom loppet av några timmar. Studenterna behandlas i princip som om de redan hade förmågan att formulera forskningsfrågor, och dessutom en så välutvecklad förmåga att de kan formulera en forskningsfråga och planera det projekt genom vilken den besvaras på en eftermiddag.

Lärandemålen framstår alltså som rimliga utifrån det som kursen gestaltar, nämligen exemplarisk forskning. Men medan alla vet att detta gestaltade innehåll bara är ett sken, tas det för givet att lärandemålen ska accepteras som riktiga beskrivningar av verkligheten. Det är denna övergång, från lekfullt gestaltad mening till allvarligt menad verklighetsbeskrivning, som ligger till grund för den gestaltande praktikens samhällsfunktion. På ett sätt som ska klargöras i det följande upprättar undervisningspraktiken, genom sin gestaltande form, ett tolkningsramverk som förklarar hur kursen förändrar de deltagande studenterna genom att ge dem, som 


\section{Sverker Lundin}

det heter i kursplanen: kunskaper, förståelse, färdigheter, förmågor, värderingsförmågor och förhållningssätt.

Förloppet där en viss mening först produceras genom gestaltande och sedan liksom magiskt förvandlas till verklighet, kan kontrasteras mot ett förlopp där studenterna, utan gestaltande moment, redan från början får ta sig an riktiga forskningsfrågor och riktig analys. Ett sådant upplägg skulle med största sannolikhet göra det uppenbart att de flesta studenter inte kan formulera sådana frågor, och än mindre producera empiri som besvarar dem, och än mindre analysera sådan empiri, och än mindre på ett bra sätt presentera några framanalyserade svar på sina frågor. Alla dessa problem undviks genom det gestaltande kursupplägget. Forskandets framgång är ju garanterad, eftersom forskningen är på låtsas och därför kan regleras i minsta detalj, som i ett skådespel. Om bara studenternas erfarenhet av låtsade frågor, analyser och svar kan omvandlas till en erfarenhet av verkliga, är givetvis detta arrangemang att föredra.

Om man lite tillspetsat kallar det förlopp som kursverksamheten gestaltar för fantasi och den värld där det finns lärandemål, kursguider, scheman, lektioner, tentor, betyg och examina för verklighet kan man säga att den avgörande mekanismen för att omvandla fantasi till verklighet är acceptans. Efter godkänd kurs behandlas kursdeltagarna formellt som om de hade uppfyllt lärandemålen. Kursen kan sedan i egenskap av godkänd ingå i en examen, och denna examen kan i sin tur användas som inträdesbiljett, till exempel till en profession. När kursdeltagarna accepterar att delta i kursen, och sedan använder sina betyg och sin examen som inträdesbiljett, handlar de som om högskolepedagogikens konstruktivistiska lärandeteorier (Biggs, 1996; Biggs \& Tang, 20II) stämmer, och som om de genom ändamålsenliga läraktiviteter hade fått alla de kunskaper och förmågor som kursplanens bolognaprocessanpassade lärandemål beskriver. Såväl studenter som lärare bidrar därmed, genom sin acceptans, till att förverkliga både lärandeteorin och lärandemålen. Till detta förverkligande bidrar givetvis också alla de som, utan att själva ha något med utbildningarna att göra, behandlar de utexaminerade studenterna som om de hade de kunskaper och kompetenser som deras examina betecknar.

Rappaport talar om denna mekanism av förverkligande i termer av "the first of ritual's fundamental offices" (I999, s. II9). Ordet "office" ska här förstås i den lite ovanliga bemärkelsen av utförandet av en uppgift (av opus=arbete och facere=göra). Att förverkliga fantasi är med andra ord det som ritualer först och främst gör - och de gör det genom att accepteras. Låt mig citera Rappaport och med utgångspunkt från det han skriver klargöra konsekvenserna av att stiliserade kursmoment där studenter får "prova på" vetenskapliga metoder accepteras:

\footnotetext{
To say that performers participate in or become parts of the orders they are realizing is to say that transmitter-receivers become fused with the messages they are transmitting and receiving. In conforming to the orders that their performances bring into being, and that come alive in their performance, performers become indistinguishable from those orders, parts of them, for the time being. Since this is the case, for performers to reject liturgical orders being realized by their own participation in them as they are participating in them is self-contradictory, and thus impossible. Therefore, by performing a liturgical order the participants accept, and indicate to themselves and to others that they accept whatever is encoded in the canon of that order. (s. II9)
}

Den "ordning" som Rappaport talar om motsvaras i vårt fall av utbildningssystemet och det moderna samhälle som utbildningssystemet är en del av. Rappaport skriver att deltagarna blir en del av, eller till och med smälter samman med denna ordning på samma gång som de bidrar till 
att göra den verklig. Karaktäriseringen av deltagarna som "sändare-mottagare" knyter an till min analogi mellan kursgenomförandet och uppförandet av en pjäs. Rappaport menar att ritualen, när den utförs, genererar ett budskap som deltagarna därmed står som avsändare till. Men de är samtidigt även budskapets mottagare. Ritualen säger därför något först och främst till deltagarna själva.

Rappaport säger att ritualer verkar verklighetsskapande genom att ge upphov till en förskjutning i tolkningen av sina egna konsekvenser. Genom sin gestaltande form flyttar ritualer fokus från de alldagliga konventioner genom vilka deras konsekvenser realiseras (i vårt fall byråkratiska regelverk) till en meningsfull logik (i vårt fall rörande förståelse, kunskap och kompetens). Om man misslyckas på en kurs i vetenskaplig metod, förstås inte detta som ett resultat av att man inte kan följa instruktionerna i en kursguide utan som en konsekvens av bristande kunskap och kompetens inom vetenskaplig metod. Det faktum att denna typ av kursmoment ges på ungefär samma sätt på många olika platser tolkas inte som resultatet av geografiskt invarianta och kontanta regelverk, utan som en konsekvens av att kursmomenten ges inom en och samma verklighet, där kunskap och kompetens inom vetenskaplig metod är lika nödvändig och lika användbar överallt.

Det är alltså denna förskjutning i tolkningen, från konvention till natur, som ligger bakom kurspraktikens verklighetsskapande funktion. Kursen utger sig för att utföras på ett visst sätt på grund av att verkligheten är på ett visst sätt. Den förutsätter, kan man säga, att verkligheten är på ett visst sätt. När kursen och dess konsekvenser accepteras, implicerar detta en acceptans av den verklighet som kursen och dess konsekvenser förutsätter. En viss verklighet accepteras som förutsatt. Därigenom görs den verklig.

\section{VARFÖR GESTALTANDE KURSUPPLÄGG ACCEPTERAS, TROTS ATT DE ÄR OREALISTISKA}

En högst befogad fråga utifrån ovanstående resonemang är emellertid vem som egentligen tror på allt detta. Vem tror att studenter som gått kurs i vetenskaplig metod bara därför kan formulera forskningsfrågor och är förtrogna med den vetenskapliga rapportens form? Är det inte tvärtom så att väldigt många är tämligen övertygade om att så inte är fallet? Men varför accepterar de i så fall denna typ av kurser? Varför protesterar de inte? Varför handlar de som om studenterna lärde sig saker som de mycket väl vet att de inte lär sig? I det här avsnittet ska jag ta upp fyra sätt att besvara dessa frågor.

\section{Rationalitetens nivå}

En första typ av svar ligger på rationalitetens nivå och är tämligen enkla: på grund av att kursdeltagande leder till uppenbara fördelar jämfört med att avstå från att delta, är det rationellt att delta, även om detta innebär att man måste spela en roll i ett litet skådespel (jfr. Rappaport, I999, s. I05). Resonemanget utgår från att medverkan i kursen är resultatet av ett medvetet beslut grundat i rationella överväganden; vinster vägs mot kostnader. Engagerat deltagande som leder till ett godkänt resultat är en förutsättning för att kunna ta examen i det utbildningsprogram där kursen ingår. Priset för detta deltagande består kanske i att man måste göra avkall på en viss integritet eller heder, förknippad med allvar och seriositet. Många räknar säkert detta personliga pris som lägre än priset för allt det praktiska och ekonomiska besvär som valet att avstå från att delta resulterar i.

\section{Den förkroppsligade vanans nivå}

Ett andra svar ligger på den förkroppsligade vanans nivå. Det bygger på idéer som utvecklats av bland andra den franske sociologen Pierre Bourdieu. Medan förklaringen i termer av rationalitet 


\section{Sverker Lundin}

betraktar mänskligt handlande som resultatet av medvetna val, betraktas handlandet här istället som resultatet av handlingsmönster som aktiveras av skilda omständigheter, utan att medvetandet nödvändigtvis varken informeras eller aktiveras. Och i den mån medvetandet är med, är det styrt och begränsat av det omedvetna, vilket gör att den bild vi eventuellt själva bär på av att tänka fritt och rationellt snarare förstås som illusion än som verklighet. Bourdieu använde termen habitus för att tala om sådana handlingsmönster. I sin förklaring av detta nyckelbegrepp använder Donald Broady följande citat, från Bourdieus Le sense pratique:

[...] habitus, system av varaktiga och överförbara dispositioner, strukturerade strukturer som är ägnade att fungera som strukturerande strukturer, det vill säga som strukturer som genererar och organiserar praktiker och representationer, vilka kan vara objektivt anpassade till sina mål utan att förutsätta någon medveten målinriktning, och utan att förmågan att bemästra de operationer som krävs för att nå dessa mål behöver vara artikulerad. Dessa system av dispositioner är objektivt 'reglerade' och de är 'reguljära' utan att alls vara resultatet av att man åtlyder regler. Allt detta gör att de är kollektivt orkestrerade utan att vara någon skapelse av en orkesterdirigents organiserande handlande. (Bourdieu, 1980, s. 88f, citerat från Broady, I998, s. I6)

Vår habitus bestämmer vad som faller sig naturligt för oss att säga och göra. Med en starkare formulering kan man säga att habitus bestämmer vad som framstår som självklart nödvändigt, lika mycket vad som framstår som orimligt och omöjligt. Vad gäller det gestaltande kursupplägget, kan habitusbegreppet användas för att sätta ord på erfarenheten av att ha gått i skolan. I skolan får man prova på det ena och det andra; lektionerna är fyllda av "realistiska" övningar (i synnerhet gäller detta matematikundervisningen, se Lundin, 20I2a). Högskolans vuxna kursdeltagare - och detta gäller såväl lärare som studenter - möter därför inte det gestaltande kursupplägget som en nyhet som förvånar. Tvärtom har de av sin skolgång förlänats en habitus som gör dem benägna att inte bara acceptera kursupplägget, utan snarare att omfamna det entusiastiskt. Med Bourdieu kan man se detta omfamnande som en förkroppsligad strategi, ett förkroppsligat framgångsrecept - för just genom att ta sig an kursen med liv och lust maximeras chansen för goda prestationer, vilka i sin tur, som vi sett, leder till sociala och materiella fördelar.

\section{Subjektiveringens nivå}

Ett tredje svar ligger på subjektiveringens nivå. Det är ett försök att undvika två motsatta brister hos de första två förklaringsvägarna: förklaringar i termer av rationella val tenderar att fästa allt för stor vikt vid det medvetna tänkandet; förklaringar i termer av habitus tenderar tvärtom att inte göra rättvisa åt människans förmåga att frigöra sig med hjälp av medveten reflektion (jfr. Boltanski, 20II). Vad vi därför på denna tredje nivå ska tillägga är att människor som regel faktiskt bär på en förmåga att genomskåda den typ av illusion som gestaltande kursupplägg opererar med. Med utgångspunkt från den österrikiske kulturteoretikern Robert Pfaller (2002) ska jag nu i större detalj utveckla vad genomskådande är och vad det får för konsekvenser.

Termen genomskådande sätter som tidigare nämnts fokus på kursuppläggets likhet med skådespeleri, lek och spel. Karaktäristiskt för denna sorts praktiker är att de upprättar en illusion som de deltagande emellertid är fullt medvetna om är just en illusion. En förutsättning för att en lek ska vara en lek är att de deltagande förstår att det är lek de är involverade i, och inte förväxlar lekens illusioner med verkligheten. Deltagande i lek aktiverar därmed vårt tänkande på ett särskilt sätt: å ena sidan kräver lekandet att vi sätter parentes kring vår normala verklighetsuppfattning och till exempel förhåller oss till ting och varelser som egentligen inte existerar, som om de existerade. Man kan leka att man har en osynlig kompis, eller att det regnar, fastän det 
inte regnar. Leken kräver att vi underordnar oss påhittade egenskaper hos dessa icke existerande entiteter - att vi pratar som om vår låtsasvän existerade, eller tar fram ett paraply fastän det inte behövs. $\AA$ andra sidan kräver leken att vi inte släpper taget om den verkliga verkligheten. Tvärtom måste den verkliga verkligheten finnas kvar som en bakgrund gentemot vilken lekens illusioner avtecknar sig. Vi måste så att säga hålla två bollar i luften samtidigt: å ena sidan den illusion som vi själva är medskapare till och som vi likväl underordnar oss, å andra sidan den "faktiska" verkligheten, vars bestämmande logik vi är införstådda med men som vi tillfälligtvis väljer att bortse från.

En första sak att notera angående detta mentala tillstånd som leken genererar är att det kan vara lustfyllt. Det kan vara roligt att leka. Själva genomskådandet är lustfyllt eftersom det placerar oss som subjekt lite ovanför de två verkligheter - den illusoriska och den verkliga - som vi opererar med. Vi kan uppleva lust av att veta mer än vi ser ut att göra; av att låta skenet bedra; vi kan glädjas åt att lite grann se ner på de dumheter vi ägnar oss åt.

En andra sak att notera är emellertid att lekande inte är så oskyldigt som man kanske tror. Känslan av att vara frikopplad från verklighetens regler och normer gör att vi ger våra känslor och vårt begär större svängrum än vanligt. Vi tillåter oss att bli mer glada, mer entusiastiska och mer arga inom lekens domäner än vad vi gör när vi befinner oss i den vanliga verkligheten. $\mathrm{Vi}$ låter oss så att säga dras med av lekens illusioner. Även om vi tror att vi underordnar oss lekens logik frivilligt, är det inte så enkelt. När vi väl gått in i lekandets tänkesätt, är vi i lekens våld. Och den drar oss inte bara med sig just då, när vi leker. Lekandet sätter även avtryck och spår. Och här passar det bra att återigen tala i termer av habitus: lekandet, i egenskap av verklig praktik där vi talar och handlar, formar vår habitus på så sätt att lekens illusioner blir en del av det vi tar för givet - inte precis som verkligt kanske, men tveklöst som en del av vår verklighet. ${ }^{4}$

Medan det framställs som att det gestaltande kursupplägget är en lekfull härmning av forskningens verklighet, är den tes som läggs fram här att kursuppläggets gestaltande praktik fungerar verklighetsskapande just genom att presentera sig själv som en oskyldig lek. Genom att framställa sig själva som uppenbart skilda från verkligheten leder kursupplägget kursdeltagarna att sänka garden och låta sig dras med av lekens illusioner. Genom att kursdeltagarna är väl medvetna om att de leker, kan deras hängivelse åt illusionerna bli lustfylld. De hänger sig åt leken, i tron att de sedan kan lämna den.

Jag vill föreslå att termen identifikation används för att tala om hur lekens verklighet, utan att vi märker vad som pågår, följer med oss och påverkar vår verklighetsuppfattning även efter det att vi tror oss ha slutat leka. Vad som sker, när vi blivit allt för vana vid att leva i lekens fantasivärld, är att vi börjar söka efter den, och kanske ibland hitta den, i verkligheten själv, utan att förstå varifrån dessa fantasier kommer. Fantasin injiceras så att säga i verkligheten själv. Man kan förstå detta i termer av habitus, det vill säga som en effekt av tillvänjning, men för den drabbade framstår det på ett närmast motsatt sätt, som om det man söker och kanske hittar vore mer verkligt än de alldagliga aspekter av tillvaron som man inte fäster sig vid.

Medan lek och verklighet tidigare existerade fredligt sida vid sida, trängs de nu på samma plats. Vi väntar nu frustrerat på vår låtsasvän; vi grämer oss över att vi står där med paraplyet uppfällt, utan att det gör någon nytta i solskenet, eller tvärtom, att vårt uppfällda låtsasparaply

4 Mitt resonemang kan jämföras med Heinz-Joachim Heydorns (1969) kritik av "learning by doing” hos Dewey. Den typ av kursmoment som jag talar om i termer av att "prova på", beskriver Heydorn i termer av framställandet av en "förenklad omvärld", som elever inom skolans ramar både tvingas frambringa och lära sig bemästra. 


\section{Sverker Lundin}

inte hjälper mot riktigt regn. Vad dessa absurda exempel motsvarar i fråga om vetenskaplig teori och metod är en förväntan på att det gestaltade kursupplägget ska leda till verkliga kunskaper om riktig forskning. Personer som är frustrerade eller arga för att detta inte sker, motsvarar i min tolkning blöta människor i regn som är frustrerade eller arga för att deras låtsasparaply inte fungerar. De har drabbats av en svårighet att skilja lek från verklighet.

Precis i motsats till den lust som är förknippad med genomskådande, tenderar identifikationens sammanblandning mellan fantasi och verklighet att vara förknippad med ilska och frustration och en lust att kritisera och korrigera. ${ }^{5}$ Termen identifikation sätter fokus just på att fantasin identifieras, i verkligheten. Vi ser fantasin där ute, som om den vore mer verklig än verkligheten själv, men på ett märkligt sätt likväl frånvarande. Identifikationen kan sägas vara resultatet av en habitus som formats genom lek. Produktionen av lekens verklighet har blivit en förkroppsligad vana. Vi kan inte låta bli att se och underkasta oss de fantasier vi blivit vana att producera. Vi kan inte låta bli att värdera och känna utifrån lekens logik.

Subjektivering, slutligen, är vad både genomskådande och identifikation leder till - nämligen två komplementära upplevelser av att "vara någon". Genomskådande hänger samman med den lustfyllda upplevelsen av att veta mer och ha kontroll. I vår acceptans av kursdeltagandet och dess konsekvenser ser vi oss själva som lekandes, det vill säga som personer som kan hålla två bollar i luften samtidigt. Vi kan skratta åt de dumheter vi deltar i och glädjas åt dem - samtidigt som vi i bästa fall får skörda frukterna av förmågan att göra det bra, och få betyg, och ta examen.

Den kursdeltagare eller lärare som när förhoppningar om att kursupplägget ska vara verkningsfullt kan emellertid inte uppleva lust på samma sätt. Hon lider och frustreras tvärtom av glappet mellan kurspraktik och forskning och av glappet mellan lärandemålens formuleringar och vad studenterna faktiskt lär sig. Min tes är emellertid att även detta lidande och denna frustration är förknippad med en sorts "njutning". Med termen njutning (till skillnad från den "lust" som jag talat om ovan) syftar jag på vad den franske psykoanalytikern Jacques Lacan på franska kallar jouissance (se t.ex. Pfaller, 2002, s. 236). På ett sätt som liknar den lustfyllda glädje som följer av genomskådande hänger även identifikationens njutning samman med en upplevelse av det egna jaget som bättre vetande. Men medan den genomskådande tycker det är lustfyllt av att placera sig själv på distans till de dumheter hon likväl deltar i, njuter den identifierande av att placera sig själv i närheten av något hon uppfattar som fantastiskt. Medan den genomskådandes lust är en följd av disidentifikation med något föraktligt och påtagligt verkligt, njuter den identifierande av identifikation med något värdefullt men plågsamt frånvarande. Identifikationens föremål är här idealiserade fantasier om den egen forskningspraktiken och kanske även vad man hade kunnat åstadkomma om man bara fått fria händer i undervisningen. Dessa fantasier krossas av mötet med den tvingande kursguiden, och läraren tvingas så att säga mot sin vilja ner på jorden, ner i smutsen, där hon upplever sig inte höra hemma. Poängen är att både genomskådande och identifikation - skillnaden mellan deras sinnesstämningar till trots

5 Pfaller (2002, s. 224ff) talar om denna effekt i termer av en "trumpen", dyster och glädjelös "sinnesstämning". Den hänger samman med vad Pfaller kallar ett "asketiskt ideal". I vårt fall handlar detta ideal om hur undervisning i metod egentligen borde bedrivas, och vilka resultat sådan undervisning egentligen borde få. Den student eller lärare som fäst sig vid ett sådant ideal är trumpen över att verkligheten inte motsvarar det. Sådana studenter och lärare kan kallas asketer, eftersom de inte tilllåter sig att ge sig hän åt verkligheten, om den inte motsvarar deras högt ställda krav. Då avstår de hellre, trumpna. Pfaller diskuterar även benägenheten hos sådana personer att engagera sig i kritik och reform (2002, s. 81-88), men här är mitt resonemang även inspirerat av den franske sociologen Luc Boltanski (2011). 
- förstår sig själva och vilka de är i termer av den mening som kursen gestaltar, och varken kan eller vill frigöra sig från denna förståelse.

Vad jag försökt visa här är att man inte behöver vara en dumbom för att låta sig dras med i ritualens verklighetsskapande logik. Tvärtom kan man vara tämligen klarsynt och kritisk - men inte desto mindre göra "sin del" av ritualens arbete.

\section{Den materialiserade ideologins nivå}

Mitt fjärde och sista svar ligger på den materialiserade ideologins nivå. ${ }^{6}$ Detta svar tar fasta på att kurser i vetenskaplig metod där man får prova på det vetenskapliga hantverket kanske inte skiljer sig så mycket från den riktiga forskningens praktik som jag i det ovanstående resonemanget tagit för givet. För kanske tar de studenter som gått den här sortens gestaltande kurser med sig detta tillvägagångssätt in i en forskarutbildning och blir godkända av samma sorts lärare som undervisar på grundutbildningen. Och kanske är skillnaden inte så avgörande mellan studenternas absolut verkningslösa inlämningsuppgifter och de forskningsrapporter, artiklar, antologier och monografier, som flödar ut ur den samhällsvetenskapliga forskningens institutioner (jfr. Alvesson, Gabriel \& Paulsen, 20I7; Porter, 1995). Kanske är med andra ord denna forskning i inte så liten grad gestaltande den också, det vill säga: kanske syftar även denna forskning först och främst till att visa upp, för de forskande själva och för omvärlden, att det faktiskt är forskning de håller på med, och till att utifrån detta självskapade tolkningsramverk - som en naturlig förlängning av utbildningssystemet - positionera forskarna i samhället.

Detta sätt att få det gestaltande kursupplägget att "smälta in" kan liknas vid att ändra verkligheten för att på så sätt lura någon att tro att en påhittad karta stämmer. Det framstår som ett väldigt besvärligt sätt att lura någon, men om man har möjlighet, tveklöst som ett synnerligen effektivt sätt. Så effektiv är faktiskt metoden att ingen efteråt skulle kunna säga säkert om kartan är riktig eller inte - eller om kanske själva verkligheten efter ändringen är falsk eftersom den stämmer överens med en påhittad karta.

En av den franske filosofen Louis Althussers (200I) nyckelidéer är att ideologi har en "materiell existens" och att sådan materiell ideologi utgör "materialiserad fantasi". Dessa formuleringar ska förstås precis i termer av att verkligheten omformats efter kartan, där kartan består av rituellt gestaltade illusioner, bland annat dem som vårt gestaltande kursupplägg producerar rörande vetenskapen.

Om vetenskapen i sina institutioner och praktiker var väsensskild från den typ av gestaltande praktiker som vi analyserar här, om vetenskapen var "på riktigt", skulle kursupplägget kunna förstås symboliskt, som ett stiliserat gestaltande av denna verklighet, som en förmedling i handling av "meningen" med forskning. Så ser emellertid inte relationen mellan kurs och forskning ut. Samhällsvetenskaplig forskning äger tvärtom till stor del rum inom samma ideologiska ram som utbildningssystemet. Samma rationella resonemang om vinster och kostnader kan ligga till grund för deltagande i gestaltande undervisning som för deltagande i gestaltande forskning; den habitus som genereras av gestaltande undervisning kan utan större översättningsarbete göras användbar även inom forskningen; det subjekt som formats av gestaltande undervisning känner bara allt för väl igen sig i forskandets verklighet, och kan antingen bekymmerslöst fortsätta att

6 Denna förklaring bygger huvudsakligen på Althussers (2001) teori om ideologiska statsapparater (ISA). Det förtjänar att nämnas att Pfaller betraktar sig själv som "althusserian" (se t.ex. Pfaller, 1997; 2015; 2016a) och att det finns en bakomliggande teoretisk koppling mellan mina resonemang kring genomskådande och identifikation, och det resonemang som förs i detta avsnitt, kring materialiserad ideologi. 


\section{Sverker Lundin}

genomskåda, eller tvärtom vara frustrerad och kritisk - nu mot det skådespeleri som krävs för att publicera och få forskningsmedel, istället för som tidigare mot det skådespeleri som krävs för att bli godkänd och ta examen.

Denna färde förklaring leder till en omformulering av trovärdighetens problem, från frågan om hur någon ska kunna tro att studenter genom det gestaltande kursupplägget faktiskt lär sig det som lärandemålen indikerar, till den mycket bredare frågan om hur någon ska kunna tro att den forskning som kursen är en introduktion till faktiskt är "riktig forskning". Vi får en förskjutning från utbildningssociologi till vetenskapssociologi. Och med denna förskjutning öppnas dörren till alla möjliga sorters frågor om vari verkligheten egentligen består. Om kursen står i samklang med en viss typ av ritualiserad eller med ett annat ord ideologisk forskning: Var finns i så fall den forskning som inte är ideologisk?

Om ideologin är ett fängelse, säger denna fjärde förklaringsnivå för det första att fängelset inte är mentalt: det har inte formen av en begränsning av vår tankeförmåga; det består inte $\mathrm{i}$ en förvrängd förståelse av hur det egentligen inte ligger till. Med hänvisning till metaforen med kartan och verkligheten betyder det att det inte existerar någon verklighet som inte redan är formad utifrån en eller annan karta. Den kritiska frågan gentemot utbildning bör därför inte vara i vilken mån den förbereder för verkligheten utanför (hög)skolan, utan vilken sådan verklighet utbildningsarrangemanget tar för given som en förutsättning och därmed bidrar till att förverkliga. För det andra innebär detta att fängelset är tämligen rymligt - eftersom det omfattar mer eller mindre hela verkligheten; vi kan röra oss i stort sett vart vi vill inom den rituellt konstituerade ordningens ramar. Samtidigt pekar denna förklaring på hur svårt det är att frigöra sig ur ideologins grepp. Det räcker inte att förändra tänkandet. Verkligheten fortsätter likväl att vara lika ideologisk som tidigare (Pfaller, 20I6b). Vad som krävs för frigörelse är inget mindre än att ett stycke kontraideologisk verklighet upprättas, där ett kontraideologiskt tänkande kan slå rot och veckla ut sig. Denna kontraideologiska plats borde givetvis vara forskningen, och undervisning om forskning borde vara en vägledning dit.

\section{AVSLUTNING}

Jag inledde med att tala om hur utbildning kommit att behandlas som ett universellt framgångsrecept i det moderna samhället för att åstadkomma allt från anställningsbarhet till demokrati. Även om det empiriska material som behandlats här är begränsat, tyder den teoretiska analysen på att det här rör sig om falska förhoppningar. Risken tycks nämligen stor att de kunskaper och kompetenser som levereras - $\mathrm{i}$ allt raskare takt och med allt större precision till en allt bredare grupp av studenter - bäst kan förstås som fantasikonstruktioner som få egentligen tror på.

Låt mig avslutningsvis bemöta två möjliga invändningar. Den första rör kursuppläggets effektivitet. Är det verkligen så dåligt som analysen här vill låta påskina? Är det tvärtom inte helt nödvändigt att nybörjare introduceras till en komplex verksamhet med hjälp av väl reglerad övning?

Mitt första svar på dessa frågor är att det väl i och för sig kan vara riktigt att nybörjare måste introduceras via förenklingar och "reglering". Problemet med den typ av verksamhet som står i analysens fokus är bara att den så att säga inte pekar i rätt riktning. I den mån kurserna utgör en introduktion till forskning, är det fråga om en forskning som även den struktureras av ambitionen att generera ett visst sken av vetenskaplighet genom uppförande. Att få utrymme att leka behöver inte vara fel - men leken måste då troligtvis ge utrymme för individuell kreativitet och inte minst för misslyckande, något som det gestaltande kursupplägget syftar till att utesluta.

$\AA$ andra sidan förtjänar det att poängteras att den personliga erfarenheten av att ta del av denna sorts kurs inte kan reduceras till den analys som genomförts här. Analysen rör sig på ett 
abstrakt plan som måste skiljas från konkret undervisning, av en given lärare med sin specifika personlighet som i ett klassrum möter en specifik uppsättning studenter, var och en med sin bakgrund, sina tidigare erfarenheter, sina ambitioner och förhoppningar och så vidare. Analysen handlar om den form som strukturerar händelseförloppet i detta klassrum men gör inte anspråk på att fånga detta händelseförlopp i sin helhet. Vad studenter och lärare faktiskt lär sig i en given kurs är enligt min mening alltid en öppen fråga.

En andra invändning kan sägas vara moralisk, och handlar om vems sida jag egentligen står på. Är inte analysen ett uttryck för förakt gentemot precis de lärare och studenter som befinner sig längst ner i den akademiska hierarkin, och som tvingas kämpa med att uppfylla de strikta ramar som statligt fastställda examensmål sätter, till exempel för lärarutbildningen? Är inte analysen ett slag nedåt, från en skribent som uppenbarligen har tillgång till ett tungt teoretiskt artilleri?

Det här är bra frågor. I analysen ovan försökte jag vara lite självironisk när jag talade om den frustrerade lärarens idealiserade fantasier om sin egen förträfflighet och hur kursguiden tvingade ner denne lärare "på jorden". Det är nämligen från utifrån perspektiv av frustrerat arbete som artikeln är författad. Artikeln handlar precis om den situation som uppstår när såväl lärare som studenter saknar utrymme att handla utifrån sitt eget omdöme och istället görs till föremål för byråkratisk manipulation. Detta är en situation som tycks bli allt vanligare i högskolan. Min förhoppning är att den analys som presenterats här ska verka frigörande, i bästa fall för både studenter och lärare. Personligen tänker jag använda artikeln som stöd när jag argumenterar för att kurser i vetenskaplig teori och metod som jag möter i mitt arbete ska fà ett annat upplägg än det som stått i fokus här.

\section{FÖRFATTARPRESENTATION}

Sverker Lundin är lektor i pedagogik på Institutionen för pedagogik och specialpedagogik (IPS) vid Göteborgs universitet. Han undervisar i en mängd olika utbildningar, bland annat Kandidatprogrammet i pedagogik, Nordisk master i aktionsforskning och Lärarutbildningen. Lundins forskning rör frågor om kunskapsproduktion inom undervisning och forskning utifrån ett historiskt och ideologikritiskt perspektiv.

\section{REFERENSER}

Althusser, L. (2001). Lenin and philosophy, and other essays. New York: Monthly Review Press.

Alvesson, M., Gabriel, Y., \& Paulsen, R. (2017). Return to meaning: a social science with something to say. Oxford: Oxford University Press.

Biggs, J. B. (1996). Enhancing teaching through constructive alignment. Higher Education, 32, s. 347-364.

Biggs, J. B., \& \& Tang, C. S. (2011). Teaching for quality learning at university: what the student does. (4., [rev.] ed.). Maidenhead: Open University Press.

Boltanski, L. (2011). On critique: a sociology of emancipation. Cambridge: Polity.

Brante, T. (2009). Vad är en profession? Teoretiska ansatser och definitioner, i Maria Lindh (red.), Vetenskap för profession, s. 15-34. Borås: Högskolan i Borås.

Brante, T. (2011). Professions as science-based occupations. Professions and Professionalism, 1 (1), s. 4-20.

Broady, D. (1998). Kapitalbegreppet som utbildningssociologiskt verktyg (Skeptronhäften No. 15). Stockholm: ILU.

Broady, D., Börjesson, M., \& Bertilsson, E. (2009). Lärarutbildningens hierarkier: Temaintroduktion. Praktiske Grunde. Nordisk tidsskrift for kultur-og samfundsvidenskab, 2009 (4).

Depaepe, M., \& Smeyers, P. (2008). Educationalization as an Ongoing Modernization Process. Educational Theory, 58 (4), s. 379-389.

Dodillet, S., Lundin, S., \& Krüger, J. O. (2018). Constructing professionalism in teacher education. Analytical tools from a comparative study. Education Inquiry, s. 1-18. 


\section{Sverker Lundin}

Gillespie, M. A. (2008). The theological origins of modernity. Chicago: University of Chicago Press.

Harrison, P. (2008). The Fall of Man and the Foundations of Science. Cambridge: Cambridge University Press. Heydorn, H.-J. (1969). Ungleichheit für Alle. Das Argument, 10, s. 361-388.

Höhne, T. (2003). Pädagogik der Wissensgesellschaft, Bielefeld: Transcript.

Krejsler, J. (2005). Professions and their Identities: How to explore professional development among (semi-) professions, Scandinavian Journal of Educational Research 49 (4), s. 335-357.

Lundin, S. (2012a). Hating School, Loving Mathematics. The ideological function of critique and reform in mathematics education. Educational Studies in Mathematics, 80 (1), s. 73-85.

Lundin, S. (2012b). Mechanism, understanding and silent practice in the teaching of arithmetic. The intention, critique and defent of Carl Alfred Nyström's Digit-Arithmetic 1853-1888. Göteborg: Institutionen för filosofi, lingvistik och vetenskapsteori, Göteborgs universitet.

Lundin, S., \& Petersen, K.-A. (2005). Rekrytering till omvardnadsutbildningar i Sverige 1993-2003: OMOM-projektet: Sjuksköterskeutbildningar: Rekrytering och yrkesidentitet under omstrukturering. Pedagogiska institutionen, Uppsala universitet.

Lundin, S., Dodillet, S., \& Storck Christensen, D. (2018). Ritual, Reform and Resistance in the Schoolified University. On the dangers of faith in education and the pleasures of pretending to taking it seriously. Confero, s. 1-32.

Lundin, S., \& Wessely, T. (2019). Den fornekade kunskapen: En introduktion till Robert Pfallers filosofi. Hägersten: Tankekraft förlag.

Oelkers, J., Osterwalder, F., \& Tenorth, H.-E. (2003). Das verdrängte Erbe. Weinheim: Beltz.

Pfaller, R. (1997). Althusser - das Schweigen im Text: Epistemologie, Psychoanalyse und Nominalismus in Louis Althussers Theorie der Lektüre. München: Fink.

Pfaller, R. (2002). Die Illusionen der anderen. Über das Lustprinzip in der Kultur. Berlin: Suhrkamp. Översatt till engelska 2014 av Lisa Rosenblatt tillsammans med Charlotte Eckler och Camilla Nielsen med titeln On the Pleasure Principle in Culture: Illusions Without Owners. Brooklyn: Verso Books.

Pfaller, R. (2015). Althusser's best tricks. Crisis \& Criqique, 2 (2), s. 25-44.

Pfaller, R. (2016a). The Althusserian Battlegrounds. i A. Hamza \& F. Ruda (red.), Slavoj Žižek and Dialectical Materialism, s. 23-41. New York: Palgrave Macmillan.

Pfaller, R. (2016b). The efficiency of ideology and the possibilities of art. Stasis, 4 (2).

Pfau, T. (2013). Minding the modern: human agency, intellectual traditions, and responsible knowledge. Notre Dame, Indiana: University of Notre Dame Press.

Pongratz, L. A. (2009). Bildung im Bermuda-Dreieck, Bologna - Lissabon - Berlin: eine Kritik der Bildungsreform. Paderborn: Schöningh.

Porter, T. M. (1995). Trust in numbers: the pursuit of objectivity in science and public life. Princeton: Princeton University Press.

Ribolits, E., \& Zuber, J. (red.). (2004). Pädagogisierung: Die Kunst, Menschen mittels Lernen immer dümmer zu machen! Innsbruck-Wien-München-Bozen: Studienverlag.

Rappaport, R. A. (1999). Ritual and religion in the making of humanity. Cambridge: Cambridge University Press.

Utredningen om högskolans utbildningsutbud. (2015). Högre utbildning under tjugo år. (SOU 2015:70). 